\title{
The effects of ventilation on left-to-right shunt and regional cerebral oxygen saturation: a self-controlled trial
}

Peiyi Li ${ }^{1,2}$, Jun Zeng' ${ }^{2}$, Wei Wei ${ }^{2^{*}}$ (D) and Jing Lin²

\begin{abstract}
Background: Increase of pulmonary vascular resistance (PVR) is an efficient method of modulating pulmonary and systemic blood flows (Qp/Qs) for patients with left-to-right (L-R) shunt, and is also closely associated with insufficient oxygen exchange for pulmonary hypoperfusion. So that it might be a preferred regime of maintaining arterial partial pressure of carbon dioxide tension $\left(\mathrm{PaCO}_{2}\right)$ within an optimal boundary via ventilation management in congenital heart disease (CHD) patients for the inconvenient measure of the PVR and Qp/Qs. However, the appropriate range of $\mathrm{PaCO}_{2}$ and patient-specific mechanical ventilation settings remain controversial for CHD children with L-R shunt.

Methods: Thirty-one pediatric patients with L-R shunt, 1-6yr of age, were included in this observation study. Patients were ventilated with tidal volume $\left(V_{T}\right)$ of 10,8 and $6 \mathrm{ml} / \mathrm{kg}$ in sequence, and $15 \mathrm{~min}$ stabilization period for individual $V_{T}$. The velocity time integral $(\mathrm{VTI})$ of $L-R$ shunt, pulmonary artery (PA) and descending aorta (DA) were measured with transesophageal echocardiography (TEE) after an initial 15 min stabilization period for each $V_{T}$, with arterial blood gas analysis. Near-infrared spectroscopy sensor were positioned on the surface of the bilateral temporal artery to monitor the change in regional cerebral oxygen saturation $\left(\mathrm{rSCO}_{2}\right)$.
\end{abstract}

Results: $\mathrm{PaCO}_{2}$ was $31.51 \pm 0.65 \mathrm{mmHg}$ at $\mathrm{V}_{\mathrm{T}} 10 \mathrm{ml} / \mathrm{kg}$ vs. $37.15 \pm 0.75 \mathrm{mmHg}$ at $\mathrm{V}_{\mathrm{T}} 8 \mathrm{ml} / \mathrm{kg}(P<0.03)$, with $44.24 \pm 0.99$ $\mathrm{mmHg}$ at $\mathrm{V}_{T} 6 \mathrm{ml} / \mathrm{kg}$ significantly higher than $37.15 \pm 0.75 \mathrm{mmHg}$ at $\mathrm{V}_{T} 8 \mathrm{ml} / \mathrm{kg}$. However, $\mathrm{PaO}_{2}$ at a $\mathrm{V}_{T}$ of $6 \mathrm{ml} / \mathrm{kg}$ was lower than that at a $\mathrm{V}_{\mathrm{T}}$ of $10 \mathrm{ml} / \mathrm{kg}(P=0.05)$. Meanwhile, $72 \%(22 / 31)$ patients had $\mathrm{PaCO}_{2}$ in the range of $40-50 \mathrm{mmHg}$ at $V_{T} 6 \mathrm{ml} / \mathrm{kg}$. VTl of L-R shunt and $P A$ at $V_{T} 6 \mathrm{ml} / \mathrm{kg}$ were lower than that at $\mathrm{V}_{T}$ of 8 and $10 \mathrm{ml} / \mathrm{kg}(P<0.05) . \mathrm{rScO}_{2}$ at a $V_{T}$ of $6 \mathrm{ml} / \mathrm{kg}$ was higher than that at a $\mathrm{V}_{T}$ of 8 and $10 \mathrm{ml} / \mathrm{kg}(P<0.05)$, with a significantly correlation between $\mathrm{rSCO}_{2}$ and $\mathrm{PaCO}_{2}(r=0.53)$. VTI of PA in patients with defect diameter $>10 \mathrm{~mm}$ was higher that that in patients with defect diameter $\leq 10 \mathrm{~mm}$.

Conclusions: Maintaining $\mathrm{PaCO}_{2}$ in the boundary of $40-50 \mathrm{mmHg}$ with $\mathrm{V}_{\mathrm{T}} 6 \mathrm{ml} / \mathrm{kg}$ might be a feasible ventilation regime to achieve better oxygenation for patients with $L-R$ shunt. Continue raising $\mathrm{PaCO}_{2}$ should be careful.

Trail registration: Clinical Trial Registry of China (http://www.chictr.org.cn) identifier: ChiCTR-OOC-17011338, prospectively registered on May 9, 2017.

Keywords: Arterial partial pressure of carbon dioxide tension, Left-to-right shunt, Pulmonary vascular resistance, Ventilation strategy

\footnotetext{
* Correspondence: weiw@scu.edu.cn

${ }^{2}$ Department of Anesthesiology, West China Hospital, Sichuan University, Guo

Xue Xiang 37, Chengdu 610041, Sichuan, China

Full list of author information is available at the end of the article
}

(c) The Author(s). 2019 Open Access This article is distributed under the terms of the Creative Commons Attribution 4.0 International License (http://creativecommons.org/licenses/by/4.0/), which permits unrestricted use, distribution, and reproduction in any medium, provided you give appropriate credit to the original author(s) and the source, provide a link to the Creative Commons license, and indicate if changes were made. The Creative Commons Public Domain Dedication waiver (http://creativecommons.org/publicdomain/zero/1.0/) applies to the data made available in this article, unless otherwise stated. 


\section{Background}

Pulmonary oxygen exchange and cardiac output $(\mathrm{CO})$ are closely associated with adequate tissue oxygenation, which could be evaluated by the ratio of pulmonary and systemic blood flow (Qp/Qs) [1]. In congenital heart disease (CHD) children with left-to-right (L-R) shunt, the ratio of Qp/Qs often more than one due to the steal of pulmonary blood flow from systemic blood flow [2], and result in pulmonary hyperperfusion and poor systemic perfusion, which was associated with seriously complications, including pulmonary hemorrhage and necrotizing enterocolitis [3].

Increasing pulmonary vascular resistance (PVR) is a double-blade sword, since it would not only augment right ventricular afterload and lessen L-R shunt [4], but also lead to the insufficient pulmonary oxygenation and deteriorate tissue oxygenation [5]. Therefore, the key regime of achieving better oxygenation in patients with L$\mathrm{R}$ shunt is to balance the PVR for a favorable ratio of Qp/Qs [6, 7]. However, precisely measuring PVR and $\mathrm{Qp} / \mathrm{Qs}$ is complicated and time-consuming in the operating room. In Reddy's study, increased PVR, CO and reduced ratio of $\mathrm{Qp} / \mathrm{Qs}$ through enhancing $\mathrm{PaCO}_{2}$ was testified [8], similar clinical phenomenon was also observed after $4 \% \mathrm{CO}_{2}$ added to the fresh gas flow in a 6year-old patient with a $4 \mathrm{~mm}$ Blalock-Taussing shunt [9]. These indicated that $\mathrm{PaCO}_{2}$ which could be noninvasively measured via blood gases is more likely to be an indicator of unstable PVR and Qp/Qs [10]. However, the definite $\mathrm{PaCO}_{2}$ level that would cause intended change in L-R shunt at patient with congenital heart lesions remain unknown. Besides, adjusting $\mathrm{PaCO}_{2}$ by ventilation management is preferred by anesthesiologists for its available and handy, compare to adding $\mathrm{CO}_{2}$ to the fresh gas. Whereas, how to maintain a favorable level of $\mathrm{PaCO}_{2}$ by regulating mechanical ventilation parameters is still unclear, and largely derived from anesthesiologist's personal experience to alleviate this unequal $\mathrm{Qp} /$ Qs distribution in patients with L-R shunt.

The aim of our study was to compare the VTI of L-R shunt, PA and DA blood flow, cerebral oxygen saturation $\left(\mathrm{rScO}_{2}\right)$ by interfering with common mechanical ventilation parameters for pediatrics: $\mathrm{V}_{\mathrm{T}} 10,8$ and $6 \mathrm{ml} /$ $\mathrm{kg}$ respectively. We attempted to find a perioperative ventilation strategy with a proper range of $\mathrm{PaCO}_{2}$ which could provide an appropriate Qp/Qs with optimal oxygen supply for children with L-R shunt.

\section{Methods}

\section{Patient}

This study was approved by Ethics Committee of West China Hospital of Sichuan University and then registered on Clinical Trial Registry of China (ChiCTROOC-17011338). Eligible subjects were clinically stable children of ASA II-III and aged 1-6years with a diagnosis of L-R shunt confirmed by echocardiography and scheduled for elective cardiac surgery. Written informed consent from parents or legal guardians was obtained. Children with pulmonary diseases, heart failure or severe arrhythmia were excluded. The case would be cancelled if had one of the followings: difficult intubation, bronchial spasm and unfinished experiment before cardiopulmonary bypass.

A standardized anesthetic protocol was administered. Electrocardiogram (ECG), peripheral oxygen saturation $\left(\mathrm{SpO}_{2}\right)$ and mean blood pressure (MAP) were performed on arrival at the operating room. General anesthesia was induced with midazolam $(0.2 \sim 0.3 \mathrm{mg} / \mathrm{kg})$, sufentanil $(1 \sim 1.5 \mu \mathrm{g} / \mathrm{kg})$ and rocuronium $(0.6 \sim 1 \mathrm{mg} / \mathrm{kg})$. After intubated a tracheal tube, bilateral lung ventilations were evaluated by auscultation. Then patients were meachanically ventilated with volume control mode (Aisys $\mathrm{CS}^{2}$, Datex-Ohmeda, WI, USA). Initial settings were $\mathrm{V}_{\mathrm{T}} 10$ $\mathrm{ml} / \mathrm{kg}$, ratio of inspiratory to expiratory at $1: 2$ and $\mathrm{FiO}_{2}$ at 0.6 , with ventilator rate adjusted according to age (1 to 3 years old: $20-25$ rates $/ \mathrm{min}, 3$ to 6 years old: $16-20$ rates/min). After induction of anesthesia, a radial arterial catheter was inserted for invasive arterial blood pressure monitoring and gas sampling. During next procedure, end-tidal carbon dioxide partial pressure $\left(\mathrm{EtCO}_{2}\right)$ and invasive arterial pressure (IAP) were monitored continuously. In addition, two sensors of cerebral oximeter (EGOS-600, Enginmed, Suzhou, China) were placed bilaterally on forehead to detect $\mathrm{rScO}_{2}$ [11].

Anesthesia was maintained with $1 \sim 2 \%$ sevofurane, additional rocuronium and sufentanil were given intravenously when necessary. Moreover, all patients received $10 \sim 15 \mathrm{ml} / \mathrm{kg}$ of crystalloid in the first hour. Core body temperature remained stable at $36^{\circ}$ to $37^{\circ} \mathrm{C}$ throughout the study.

\section{Experiment protocol}

After intubation, all children were ventilated in three level of $\mathrm{V}_{\mathrm{T}}$ in the order of $10 \mathrm{ml} / \mathrm{kg}, 8 \mathrm{ml} / \mathrm{kg}$ and $6 \mathrm{ml} /$ $\mathrm{kg}$. Each $\mathrm{V}_{\mathrm{T}}$ level was maintained for $15 \mathrm{~min}$. TEE examinations and blood gas measurement were performed after 15 min of stabilization ventilation at each $\mathrm{V}_{\mathrm{T}}$ level. Data of $\mathrm{rScO}_{2}$ was automatic recording every $3 \mathrm{~s}$ during the operation and downloaded to a storage disk for further analysis after surgery.

\section{TEE measurements}

TEE, regarding as a reliable and minimally invasive monitoring technology, had been used in cardiac surgery [12]. Descending aorta blood flow (DA) which occupies almost $70 \%$ of CO could reflect the change in systemic blood flow. The velocity time integral (VTI) of L-R shunt, pulmonary artery (PA) and DA were measured respectively to represent blood flow assuming that the 
diameters of arteries changed subtly than arterioles by $\mathrm{PaCO}_{2}[13,14]$.

Detailed TEE measurements as follows: a TEE probe was inserted after intubation, and connected to an ultrasound system (Philips iE33, Bothell, WA, USA). M-line, color flow and spectral Doppler were used to measure the VTI of blood flow, assuring the angel between beam $\mathrm{M}$-line and flow smaller than $20^{\circ}$. Once $15 \mathrm{~min}$ ventilation of $\mathrm{V}_{\mathrm{T}} 10 \mathrm{ml} / \mathrm{kg}$ completed, the L-R shunt and PA flows were obtained at optimal TEE views, such as midesophageal (ME) four chamber and ME right ventricle inflow-outflow. The blood flow of DA was acquired via long-axis view of ascending aorta with the depth of TEE probe kept at mid-esophageal (ME) [15]. After 15 min of stabilization at following $\mathrm{V}_{\mathrm{T}}$ level, the identical TEE views with $\mathrm{V}_{\mathrm{T}} 10 \mathrm{ml} / \mathrm{kg}$ were scanned to acquire the VTI in each patient. All VTI of L-R shunt, PA and DA flows were traced and averaged over three consecutive cardiac cycles (Fig. 1a, b). All echocardiography recordings were obtained and analyzed by the same manipulator.

\section{Statistical analysis}

A preliminary test of 5 patients revealed that at least 24 children were needed to detect a significant difference among three $V_{T}$ assuming $\alpha=0.05$ and $\beta=0.8$. Data were tested for distribution and presented as mean $\pm \mathrm{SD}$. Differences among three $V_{T}$ were analyzed using Related-Samples Wilcoxon Signed Rank test. The

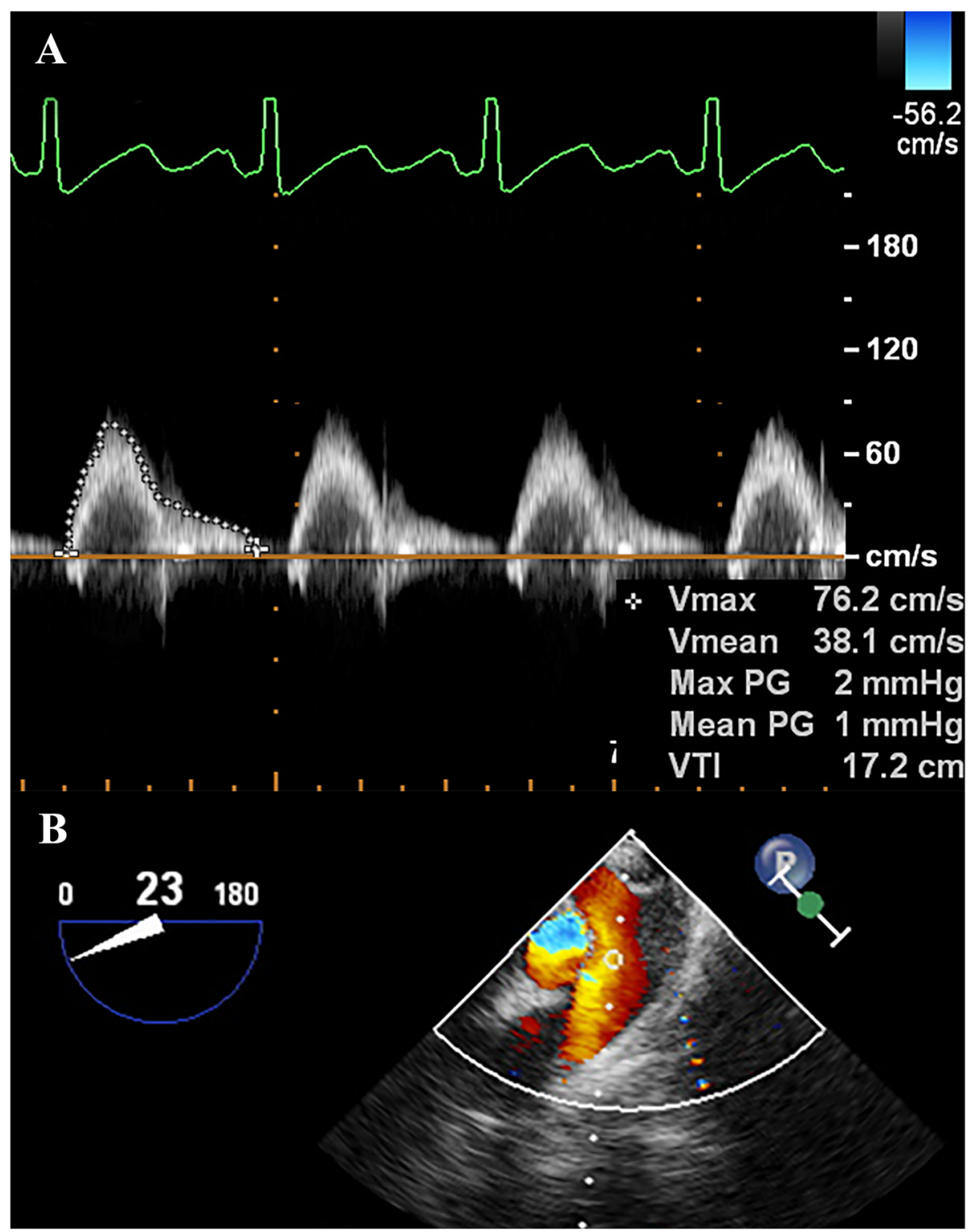

Fig. 1 A 11-year-old patient diagnosed with VSD. VTI of PA were measured respectively at short axis of ascending aorta (a, b) 
differences of between-group were evaluated by Student's t-test. Besides, Spearman correlation test was performed to access correlations. $P$ value of $<0.05$ was considered statistically significant. All statistical analyses were performed with IBM SPSS Statistics 24 (SPSS, Inc., IL, USA).

\section{Results}

All enrolled patients had completed and 93 TEE measurements was successfully obtained (Table 1). There was a statistically significant increase in $\mathrm{PaCO}_{2}$ and $\mathrm{rScO}_{2}$ as $\mathrm{V}_{\mathrm{T}}$ progressive decreased from $10 \mathrm{ml} / \mathrm{kg}$ to 8 $\mathrm{ml} / \mathrm{kg}$ and $6 \mathrm{ml} / \mathrm{kg}$ (Table 2). Low $\mathrm{PaCO}_{2}$ (below than $30 \mathrm{mmHg}$ ) occurred in $11 / 31$ patients at $\mathrm{V}_{\mathrm{T}} 10 \mathrm{ml} / \mathrm{kg}$, and 5/31 patients occurred high $\mathrm{PaCO}_{2}$ (above than 50 $\mathrm{mmHg}$ ) at $\mathrm{V}_{\mathrm{T}} 6 \mathrm{ml} / \mathrm{kg}$. In addition, the proportion of $\mathrm{PaCO}_{2}$ between 40 and $50 \mathrm{mmHg}$ increased from $0 \%$ in $\mathrm{V}_{\mathrm{T}} 10 \mathrm{ml} / \mathrm{kg}$ to $34 \%$ in $\mathrm{V}_{\mathrm{T}} 8 \mathrm{ml} / \mathrm{kg}$, and $72 \%$ among the $\mathrm{V}_{\mathrm{T}} 6 \mathrm{ml} / \mathrm{kg}$.

Figure 2 delineated a significantly stepwise decline in VTI of L-R shunt (from $60.16 \pm 6.0 \mathrm{~cm}$ to $50.35 \pm 5.12$ $\mathrm{cm}$ and $43.44 \pm 5.11 \mathrm{~cm})$. Meanwhile, the corresponding VTI of PA markedly descended from $26.36 \pm 1.68 \mathrm{~cm}$ to $26.33 \pm 1.82 \mathrm{~cm}$ and $23.23 \pm 1.55 \mathrm{~cm}$ with $\mathrm{V}_{\mathrm{T}} 6 \mathrm{ml} / \mathrm{kg}$ compared to 10 and $8 \mathrm{ml} / \mathrm{kg}$. Nevertheless, no obvious changes was found in the VTI of DA flow. Concurrently, the hypoventilation also resulted in a relatively slight but consistent reduction in the ratio of VTI ${ }_{\mathrm{PA}} / \mathrm{VTI}{ }_{\mathrm{DA}}$ (Table 2).

The mean value of $\mathrm{VTI}_{\mathrm{PA}} / \mathrm{VTI}_{\mathrm{DA}}$ was lower in the group of $\mathrm{PaCO}_{2}$ higher than $40 \mathrm{mmHg}$ (1.85 vs 1.67 ), but without statistical significance. Meanwhile, the $\mathrm{rScO}_{2}$ risen $2.78 \%$ significantly following $\mathrm{PaCO}_{2}$ higher than $40 \mathrm{mmHg}$ (from 62.14 to $64.92 \%$ ), with a significant linear correlation between $\mathrm{PaCO}_{2}$ and $\mathrm{rScO}_{2}(\mathrm{r}=0.53)$ depicted in Fig. 3.

Children with defect $>10 \mathrm{~mm}$ were younger, accompanied by higher VTI of PA flow and longer hospitalization days (Table 3). In addition, the decrease of L-R shunt caused by rising $\mathrm{PaCO}_{2}$ was more striking in children

Table 1 Patients' preoperative characteristics and operative details

\begin{tabular}{ll}
\hline Age (month) & $33.52 \pm 3.44$ \\
Weight $(\mathrm{kg})$ & $13.01 \pm 0.79$ \\
Height $(\mathrm{cm})$ & $90.42 \pm 4.0$ \\
Sex (Male/Female) & $17 / 14$ \\
Type of defect (PDA/ASDNSD) & $1 / 5 / 25$ \\
Diameter of defect (mm) & $9.81 \pm 1.26$ \\
Length of surgery (hour) & $3.51 \pm 0.31$ \\
\hline ASD Atrial septal defect, PDA Patent ductus arteriosus, VSD Ventricular \\
septal defect
\end{tabular}

whose defect $\leq 10 \mathrm{~mm}$ rather than children with defect> 10 $\mathrm{mm}$, although without significant difference.

\section{Discussion}

In the present study, hyperventilation with $\mathrm{V}_{\mathrm{T}} 10 \mathrm{ml} / \mathrm{kg}$ aggravated the VTI of L-R shunt and reduced $\mathrm{rScO}_{2}$ for pediatric patients with $\mathrm{CHD}$, inversely, hypoventilation with $V_{\mathrm{T}} 6 \mathrm{ml} / \mathrm{kg}$ evoked moderate hypercapnia indicated with mitigating the excessive $\mathrm{L}-\mathrm{R}$ shunt and raising $\mathrm{rScO}_{2}$.

Hyperventilation has traditionally been preferred to improve pulmonary oxygen exchange and reduce the incidence of perioperative desaturation. However, it may be harmful for CHD children with L-R shunt as the fragile balance of Qp/Qs might be exacerbated by decrease of $\mathrm{PaCO}_{2}[16,17]$. Seriously, the increase of Qp/Qs may result in imbalance of oxygen supply and postoperative mortality $[18,19] . \mathrm{CO}_{2}$ could increase the extracellular concentration of $\mathrm{Ca}^{2+}$, constrict pulmonary arterioles and lead to an increase of PVR [20], which is likely to result in a reduction in L-R shunt and redistribute the blood from PA to the systemic blood flow. In this study, we founded the VTI of L-R shunt decreased by $27.8 \%$ as $\mathrm{PaCO}_{2}$ increased from $31 \mathrm{mmHg}$ to $44 \mathrm{mmHg}$, meanwhile the VTI of PA decreased by $11.9 \%$, without significant increase in the DA blood flow and MAP. The possible explanation was that the DA blood flow represented about $70 \%$ of $\mathrm{CO}$, which may underestimate the slightly increase of systemic blood flow.

Previous studies demonstrated that adjusting Qp/Qs via ventilation strategies was an effective method in children with intra-cardiac shunt $[21,22]$. We decreased the $\mathrm{V}_{\mathrm{T}}$ from $10 \mathrm{ml} / \mathrm{kg}$ to $6 \mathrm{ml} / \mathrm{kg}$ in this population, and the increase of $\mathrm{PaCO}_{2}$ led to a decrease in $\mathrm{VTI}_{\mathrm{PA}} / \mathrm{VTI}_{\mathrm{DA}}$, Fajardo et al. also came to the same conclusion [7]. Despite the ventilation strategies of increased PVR differed in some way, but the ultimately outcomes of lower L-R shunt was coincident. The decrease of $\mathrm{VTI}_{\mathrm{PA}} / \mathrm{VTI}_{\mathrm{DA}}$ in

Table 2 Hemodynamics and other parameters with $V_{T}$ 10, 8 and $6 \mathrm{ml} / \mathrm{kg}$

\begin{tabular}{llll}
\hline & $V_{T} 10 \mathrm{ml} / \mathrm{kg}$ & $V_{T} 8 \mathrm{ml} / \mathrm{kg}$ & $V_{T} 6 \mathrm{ml} / \mathrm{kg}$ \\
\hline IAP $(\mathrm{mmHg})$ & $65.35 \pm 2.15$ & $62.39 \pm 2.11$ & $61.23 \pm 2.52$ \\
$\mathrm{HR}$ (beats/min) & $107.81 \pm 3.45$ & $105.58 \pm 3.07$ & $114.26 \pm 3.01$ \\
$\mathrm{VTI}{ }_{\mathrm{PA} N \mathrm{NTI}} \mathrm{DA}$ & $1.83 \pm 0.14$ & $1.80 \pm 0.15$ & $1.71 \pm 0.13$ \\
$\mathrm{rScO}_{2}(\%)$ & $67.23 \pm 4.72$ & $67.55 \pm 4.54$ & $69.34 \pm 4.29^{* \#}$ \\
$\mathrm{EtCO}_{2}(\mathrm{mmHg})$ & $30.87 \pm 0.52$ & $36.68 \pm 0.69^{*}$ & $44.45 \pm 1.06^{* \#}$ \\
$\mathrm{PaCO}_{2}(\mathrm{mmHg})$ & $31.51 \pm 0.65$ & $37.15 \pm 0.75^{*}$ & $44.24 \pm 0.99^{* \#}$ \\
$\mathrm{PaO}_{2}(\mathrm{mmHg})$ & $216.89 \pm 10.72$ & $214.89 \pm 9.87$ & $203.74 \pm 8.97^{*}$ \\
\hline $\mathrm{ECO}_{2} \mathrm{End}^{*}$
\end{tabular}

EtCO ${ }_{2}$ End-tidal carbon dioxide partial pressure, $H R$ Heart rate, IAP Invasive arterial pressure, $\mathrm{PaCO}_{2}$ Arterial partial pressure of carbon dioxide tension, $\mathrm{PaO}_{2}$ Arterial oxygen pressure, $r \mathrm{SCO}_{2}$ Regional cerebral oxygen saturation, $V_{T}$ Tidal volume

${ }^{*} P<0.05$ Respect to $V_{\mathrm{T}} 10 \mathrm{ml} / \mathrm{kg} ;{ }^{\#} P<0.05$ Respect to $V_{\mathrm{T}} 8 \mathrm{ml} / \mathrm{kg}$ 


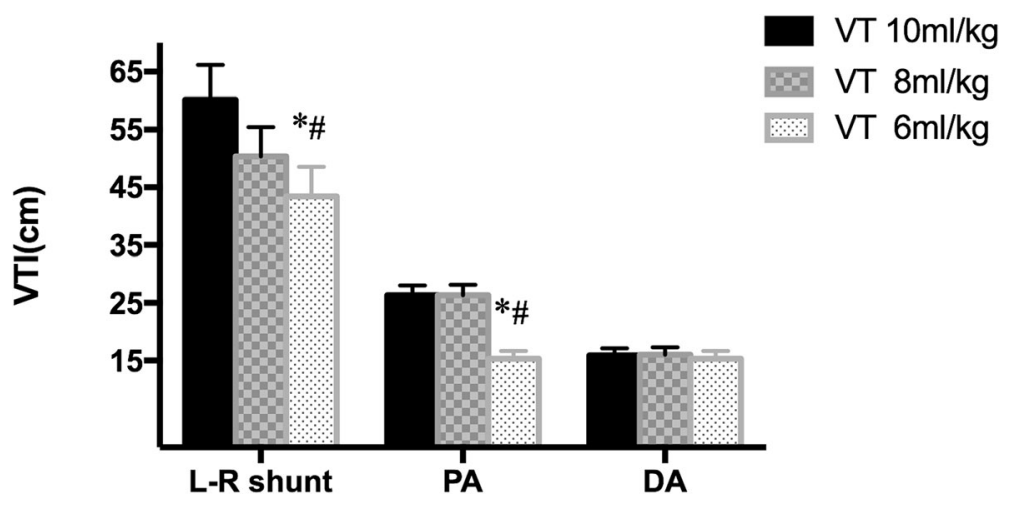

Fig. 2 Changes in VTI of L-R shunt, PA and DA with $V_{T} 10,8$ and $6 \mathrm{ml} / \mathrm{kg}$. ${ }^{*} P<0.05$ respect to $V_{T} 10 \mathrm{ml} / \mathrm{kg},{ }^{\#} P<0.05$ respect to $V_{T} 8 \mathrm{ml} / \mathrm{kg}$

our results mainly attributed to the decreased L-R shunt and PA blood flow, which was also testified in another study, in which an increase in $\mathrm{PaCO}_{2}$ from $55 \mathrm{mmHg}$ even $90 \mathrm{mmHg}$ incurred statistically significant reduction in Qp/Qs [23]. Nevertheless, our modest but insignificant decrease of $\mathrm{VTI}_{\mathrm{PA}} / \mathrm{VTI}_{\mathrm{DA}}$ was the consequent of confined fluctuate range of $\mathrm{PaCO}_{2}$ in our study: merely $30 \mathrm{mmHg}$ to $50 \mathrm{mmHg}$ considering the clinical safety.

Bradely et al.demonstrated that hypoventilation improves cerebral blood flow velocity in infants with bidirectional superior cavopulmonary connection [24], and $\mathrm{rSCO}_{2}$ was associated with the change of cerebral blood perfusion [25]. In this study, we found increase of $\mathrm{rSCO}_{2}$ in accordance of increase of $\mathrm{PaCO}_{2}$. One reason might be that dilated cerebrovascular induced by increased $\mathrm{PaCO}_{2}[26,27]$. Another possible reason was increased CO for decrease of L-R shunt and PA flow while DA remain unchanged. It's seems that the cerebrovascular dilation component was predominated contributor to the increased $\mathrm{rSCO}_{2}$.

Previous studies have suggested that hypocarbia alkalosis should be vigilant in children with elevated

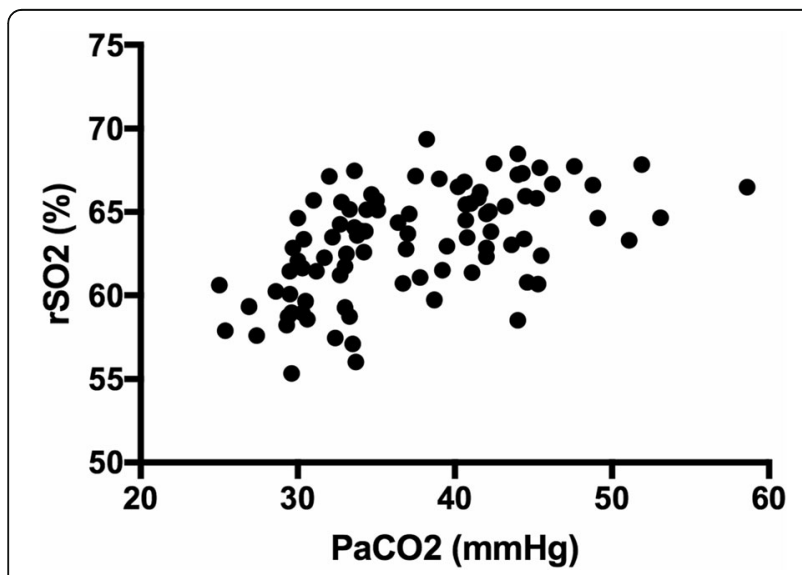

Fig. 3 There was significant correlations between $\mathrm{rSCO}_{2}$ and $\mathrm{PaCO}_{2}$ $(r=0.53, P=0.03)$ pulmonary artery tension due to pulmonary vasodilation [28]. But it need be cautious that although hypercarbia could induce a series of advantages, including mitigated the pulmonary over-circulation and dilated cerebral vascular bed, as indicated by decreased L-R shunt, PA blood flows and $\mathrm{VTI}_{\mathrm{PA}} / \mathrm{VTI}_{\mathrm{DA}}$ and increased $\mathrm{rSCO}_{2}$ in our study. Nonetheless, hypercarbia would also cause disadvantage of decreased $\mathrm{PaO}_{2}$ by alveolar hypoventilation. Pervious study founded systemic oxygen saturation initially improved as the Qp/Qs declined in animals modes, whereas decreased reversely after the Qp/Qs below than 0.7 [29]. Moreover, the hypercarbic probably induced an increase in heart rate, even arrhythmia and acute right heart failure which might be undesirable for the adequate oxygen supply during perioperative. As our results manifested, $\mathrm{PaO}_{2}$ decreased from 216.89 to $203.74 \mathrm{mmHg}$ as $\mathrm{PaCO}_{2}$ increased, accompanied by a small rise in $\mathrm{HR}$. Therefore maintaining the ratio of $\mathrm{Qp} / \mathrm{Qs}$ near 1 both

Table 3 Differences between different defect diameters

\begin{tabular}{lll}
\hline & $\begin{array}{l}\text { Defect } \\
\text { diameter } \\
\leq 10 \mathrm{~mm}\end{array}$ & $\begin{array}{l}\text { Defect diameter } \\
>10 \mathrm{~mm}\end{array}$ \\
\hline Number of patients & 20 & 11 \\
Age (month) & $36.19 \pm 3.89$ & $23.82 \pm 3.56^{*}$ \\
Weight (kg) & $12.95 \pm 0.99$ & $11.88 \pm 1.37$ \\
Height (cm) & $92.67 \pm 3.89$ & $84.18 \pm 3.57$ \\
VTI of L-R shunt (cm) & $58.02 \pm 5.36$ & $39.12 \pm 10.34$ \\
VTI of PA (cm) & $22.86 \pm 6.26$ & $30.54 \pm 3.16^{*}$ \\
VTI of DA (cm) & $15.01 \pm 5.68$ & $18.86 \pm 2.73$ \\
$\Delta V T I$ of L-R shunt (cm) & $19.74 \pm 4.14$ & $12.44 \pm 3.9$ \\
VTI PANTI DA & $1.75 \pm 0.67$ & $1.93 \pm 0.2$ \\
rSCO 2 (\%) & $63.66 \pm 2.26$ & $61.89 \pm 0.51$ \\
Hospitalization stay (day) & $9.95 \pm 5.01$ & $16.55 \pm 2.15^{*}$
\end{tabular}

$\Delta \mathrm{VTI}$ which indicated the absolute decrease of L-R shunt, was calculated by the absolute difference between the maximum and minimum of L-R shunt among three $\mathrm{V}_{\mathrm{T}}$

${ }^{*} P<0.05$ respect to patients with defect diameter smaller than $10 \mathrm{~mm}$ 
balance systemic blood flow and pulmonary venous oxygen content is a focus for anesthesiologists during surgery of children with L-R shunt. As seen in our results, rising $\mathrm{PaCO}_{2}$ from 31.51 to $44.24 \mathrm{mmHg}$ decreased the $\mathrm{VTI}_{\mathrm{PA}} /$ $\mathrm{VTI}_{\mathrm{DA}}$ absolute 0.12 and increased $\mathrm{rSCO}_{2}$ almost $2 \%$, meanwhile, $\mathrm{PaCO}_{2}$ in 22 children were between 40 and $50 \mathrm{mmHg}$ at $\mathrm{V}_{\mathrm{T}} 6 \mathrm{ml} / \mathrm{kg}$. Hence, maintaining $\mathrm{PaCO}_{2}$ between 40 and $50 \mathrm{mmHg}$ by $\mathrm{V}_{\mathrm{T}} 6 \mathrm{ml} / \mathrm{kg}$ is favorable for children with L-R shunt, in part because of reductions in L-R shunt and pulmonary blood perfusion and in part because of an increase in $\mathrm{rSCO}_{2}$. And it may be unwise to concentrate on minimizing L-R shunt, $\mathrm{PA}$ and $\mathrm{VTI}_{\mathrm{PA}} /$ $\mathrm{VTI}_{\mathrm{DA}}$ through limitless increasing $\mathrm{PaCO}_{2}$, ignoring risks of pulmonary hypoperfusion [30]. Besides, consecutively monitoring $\mathrm{EtCO}_{2}$ could be used as a convenient method to prevent excessively high $\mathrm{PaCO}_{2}$ [31].

For children with defect $>10 \mathrm{~mm}$, their higher VTI of $\mathrm{PA}$ and lower intraoperative $\mathrm{rSCO}_{2}$ may result from the excessive pulmonary hyperperfusion and relatively insufficient of cerebral blood flow [32]. The prolonged length of stays in defect $>10 \mathrm{~mm}$ was consistent with previous postoperative follow-up study, in which an increased risk of postoperative cognitive impairment and a significantly prolonged LOS in patients with low intraoperative $\mathrm{rSCO}_{2}$ were revealed [33]. The possible reason of the weaker vascular reactivity to higher $\mathrm{PaCO}_{2}$ in children with defect $>10 \mathrm{~mm}$ may accounted for their excessive pulmonary blood flow [34], which has been suggested produce alterations in the pulmonary vasculature, including vasoocclusive intimal thicking and medical hypertrophy [35]. Extremely patients finally evolved with obliterative pulmonary vascular disease. In previous case, children who may already been developed in pulmonary vascular obstructive disease only improved lower $\mathrm{CO}$ via banding the pulmonary artery, but without reactivity at a high level of $\mathrm{PaCO}_{2}$ [36]. Thus, we need realized that adjusting the ratio of $\mathrm{Qp} / \mathrm{Qs}$ by increasing $\mathrm{PaCO}_{2}$ may not always be applicable to all patients, especially for children older than 18 month with defect> $10 \mathrm{~mm}$. Other measures of changing PVR or SVR should take into consideration individually. Furthermore, the various pulmonary vascular response to $\mathrm{PaCO}_{2}$ may be used to estimate the magnitude of pulmonary hypertension and severity of disease.

One of the limitations of this explorative study is the limited range of $\mathrm{PaCO}_{2}$ concerning patients' safety, which contributed to the weeny decrease in $\mathrm{VTI}_{\mathrm{PA}}$ / $\mathrm{VTI}_{\mathrm{DA}}$ in our results didn't achieved statistical significance. Moreover, control the enrollment age within 18 month may prevent pulmonary arteriosclerosis from affecting outcomes. Therefore, further studies are still need to evaluate the effects of hypoventilation on children of different ages and defect types with L-R shunt, and develop individualized ventilation settings to optimize the Qp/Qs under various pulmonary vascular reactivity.

\section{Conclusions}

In conclusion, our findings recommended a feasible perioperative ventilation strategy for children with $\mathrm{L}-\mathrm{R}$ shunt. That is maintaining $\mathrm{PaCO}_{2}$ at $40-50 \mathrm{mmHg}$ by $\mathrm{V}_{\mathrm{T}}$ $6 \mathrm{ml} / \mathrm{kg}$ would be helpful to mitigate the excessive L-R shunt after anesthesia, and achieve a favorable $\mathrm{VTI}_{\mathrm{PA}} /$ $\mathrm{VTI}_{\mathrm{DA}}$ accompanied by an improvement in cerebral blood perfusion.

\section{Abbreviations \\ CHD: Congenital heart disease; DA: Descending aorta; $\mathrm{EtCO}_{2}$ : End-tidal carbon dioxide partial pressure; IAP: Invasive arterial pressure; L-R: Left-to- Right; NIRS: Near-infrared spectroscopy; PA: Pulmonary artery; $\mathrm{PaCO}_{2}$ : Arterial partial pressure of carbon dioxide tension; PVR: Pulmonary vascular resistance; $\mathrm{rSCO}_{2}$ : Regional cerebral oxygen saturation; TEE: Transesophageal echocardiography; $V_{T}$ : Tidal volume; VTI: Velocity time integral}

\section{Acknowledgements}

The authors thank all the teachers, students and the research participants who took part in the data collection. We would like to acknowledge Dr. Yiping Bai and Dr. Hong Yu for their assistance in making this a better article. We also thank Mr. Jiapei Yang and Mrs. Haili Zhang for the assistance in the research.

\section{Authors' contributions}

PY-L: ethics approve, study design, data collection and analysis, drafted the manuscript; JZ: methodology, reviewed manuscript for important intellectual content; WW: study design, data collection, data curation and reviewed it for important intellectual content; JL: reviewed it for important intellectual content. All authors read and approved the final manuscript.

\section{Funding}

This research was financially supported by research grants from the 1.3.5 project for disciplines of excellence, West China Hospital, Sichuan University (Zy2016101) and Taipei Cheng Hsin General Hospital (CHGH105-1). None of funding bodies had any influence on the design of the study and collection, analysis, and interpretation of data and in writing the manuscript.

\section{Availability of data and materials}

All data generated or analyzed during this study are available from the corresponding author on reasonable request.

\section{Ethics approval and consent to participate}

This study was approved by Ethics Committee of West China Hospital of Sichuan University and then registered on Clinical Trial Registry of China (OOC17011338. Peiyi Li/Wei Wei. Registered 9 May, 2017). Written informed consent from parents or legal guardians was obtained prior to enrollment.

\section{Consent for publication}

Not applicable.

\section{Competing interests}

The authors declare that they have no competing interests.

\section{Author details}

'Institute of Hospital Management, West China Hospital, Sichuan University, Guo Xue Xiang 37, Chengdu, Sichuan, China. ${ }^{2}$ Department of Anesthesiology, West China Hospital, Sichuan University, Guo Xue Xiang 37, Chengdu 610041, Sichuan, China. 
Received: 5 September 2018 Accepted: 20 September 2019

Published online: 09 October 2019

\section{References}

1. Brienza N, Biancofiore G, Cavaliere F, Corcione A, De Gasperi A, De Rosa RC, et al. Clinical guidelines for perioperative hemodynamic management of non cardiac surgical adult patients. Minerva Anestesiol. 2019. https://doi.org/ 10.23736/S0375-9393.19.13584-5.

2. Yamasaki Y, Kawanami S, Kamitani T, Sagiyama K, Sakamoto I, Hiasa Kl, et al. Noninvasive quantification of left-to-right shunt by phase contrast magnetic resonance imaging in secundum atrial septal defect: the effects of breath holding and comparison with invasive oximetry. Int J Cardiovasc Imaging. 2018;34(6):931-7.

3. Kitterman JA, Edmunds LH Jr, Gregory GA, Heymann MA, Tooley WH, Rudolph AM. Patent ducts arteriosus in premature infants. Incidence, relation to pulmonary disease and management. N Engl J Med. 1972; 287(10):473-7.

4. Wheller J, George BL, Mulder DG, Jarmakani JM. Diagnosis and management of postoperative pulmonary hypertensive crisis. Circulation. 1979;60(7):1640-4

5. Liu W, Huang $Q$, Lin D, Zhao L, Ma J. Effect of lung protective ventilation on coronary heart disease patients undergoing lung cancer resection. J Thorac Dis. 2018;10(5):2760-70.

6. Pinsky MR. The hemodynamic consequences of mechanical ventilation: an evolving story. Intensive Care Med. 1997;23(5):493-503.

7. Fajardo MF, Claure N, Swaminathan S, Sattar S, Vasquez A, D'Ugard C, et al. Effect of positive end-expiratory pressure on ductal shunting and systemic blood flow in preterm infants with patent ductus arteriosus. Neonatology. 2014;105(1):9-13.

8. Reddy VM, Liddicoat JR, Fineman JR, McElhinney DB, Klein JR, Hanley FL. Fetal model of single ventricle physiology: hemodynamic effects of oxygen, nitric oxide, carbon dioxide, and hypoxia in the early postnatal period. J Thorac Cardiovasc Surg. 1996;112(2):437-49.

9. Jobes DR, Nicolson SC, Steven JM, Miller M, Jacobs ML, Norwood WI Jr. Carbon dioxide prevents pulmonary overcirculation in hypoplastic left heart syndrome. Ann Thorac Surg. 1992;54(1):150-1.

10. Misra S, Koshy T, Mahaldar DA. Sudden decrease in end-tidal carbon-dioxide in a neonate undergoing surgery for type B interrupted aortic arch. Ann Card Anaesth. 2011:14(3):206-10.

11. Dix LM, van Bel F, Lemmers PM. Monitoring cerebral oxygenation in neonates: an update. Front Pediatr. 2017:5:46.

12. Schober P, Loer SA, Schwarte LA. Perioperative hemodynamic monitoring with transesophageal Doppler technology. Anesth Analg. 2009;109(2):340-53.

13. Nagi MM, Ward ME. Modulation of myogenic responsiveness by $\mathrm{CO} 2$ in rat diaphragmatic arterioles: role of the endothelium. Am J Phys. 1997;272(3 Pt 2):H1419-25.

14. Green JF, Schmidt ND. Mechanism of hyperpnea induced by changes in pulmonary blood flow. J Appl Physiol Respir Environ Exerc Physiol. 1984; 56(5):1418-22.

15. Sreedhar R. Acyanotic congenital heart disease and transesophageal echocardiography. Ann Card Anaesth. 2017;20(Supplement):S36-s42.

16. Sousse LE, Herndon DN, Andersen CR, Ali A, Benjamin NC, Granchi T, et al. High tidal volume decreases adult respiratory distress syndrome, atelectasis, and ventilator days compared with low tidal volume in pediatric burned patients with inhalation injury. J Am Coll Surg. 2015;220(4):570-8.

17. Bradley SM, Simsic JM, Mulvihill DM. Hyperventilation impairs oxygenation after bidirectional superior cavopulmonary connection. Circulation. 1998; 98(19 Suppl):II372-6 discussion II6-7.

18. McElhinney DB, Marianeschi SM, Reddy VM. Additional pulmonary blood flow with the bidirectional Glenn anastomosis: does it make a difference? Ann Thorac Surg. 1998;66(2):668-72.

19. Mainwaring RD, Lamberti JJ, Uzark K, Spicer RL, Cocalis MW, Moore JW. Effect of accessory pulmonary blood flow on survival after the bidirectional Glenn procedure. Circulation. 1999;100(19 Suppl):li151-6.

20. Horimoto M. Measurements of blood flow velocity in pulmonary microvessels with laser-Doppler microscope and investigation of several factors affecting the blood flow velocity (author's transl). Hokkaido lgaky Zasshi. 1981;56(5):507-18.
21. Lellouche F, Delorme M, Bussieres J, Ouattara A. Perioperative ventilatory strategies in cardiac surgery. Best Pract Res Clin Anaesthesiol. 2015;29(3):381-95

22. White FN, Hicks JW, Ishimatsu A. Relationship between respiratory state and intracardiac shunts in turtles. Am J Phys. 1989;256(1 Pt 2):R240-7.

23. Tabbutt S, Ramamoorthy C, Montenegro LM, Durning SM, Kurth CD, Steven $J M$, et al. Impact of inspired gas mixtures on preoperative infants with hypoplastic left heart syndrome during controlled ventilation. Circulation. 2001;104(12 Suppl 1):1159-64.

24. Bradley SM, Simsic JM, Mulvihill DM. Hypoventilation improves oxygenation after bidirectional superior cavopulmonary connection. J Thorac Cardiovasc Surg. 2003;126(4):1033-9.

25. Yagi $Y$, Yamamoto M, Saito H, Mori T, Morimoto $Y$, Oyasu T, et al. Changes of cerebral oxygenation in sequential Glenn and Fontan procedures in the same children. Pediatr Cardiol. 2017;38(6):1215-9.

26. Hoskote A, Li J, Hickey C, Erickson S, Van Arsdell G, Stephens D, et al. The effects of carbon dioxide on oxygenation and systemic, cerebral, and pulmonary vascular hemodynamics after the bidirectional superior cavopulmonary anastomosis. J Am Coll Cardiol. 2004;44(7):1501-9.

27. Park CS, Kwak JG, Lee C, Lee CH, Lee SK, Kim YL. Near-infrared spectroscopy as a possible device for continuous monitoring of arterial carbon dioxide tension during cardiac surgery. Perfusion. 2011:26(6):524-8.

28. Schuller JL, Bovill JG, Nijveld A. End-tidal carbon dioxide concentration as an indicator of pulmonary blood flow during closed heart surgery in children. A report of two cases. Br J Anaesth. 1985;57(12):1257-9.

29. Barnea O, Austin EH, Richman B, Santamore WP. Balancing the circulation: theoretic optimization of pulmonary/systemic flow ratio in hypoplastic left heart syndrome. J Am Coll Cardiol. 1994;24(5):1376-81.

30. Li J, Zhang G, Holtby H, Bissonnette B, Wang G, Redington AN, et al. Carbon dioxide--a complex gas in a complex circulation: its effects on systemic hemodynamics and oxygen transport, cerebral, and splanchnic circulation in neonates after the Norwood procedure. J Thorac Cardiovasc Surg. 2008; 136(5):1207-14

31. Smolinsky AK, Shinfeld A, Paret G, Bar-El Y, Glauber V, Shabtai EL, et al. Endtidal $\mathrm{CO} 2$ levels are a reliable indicator of band tightness in pulmonary artery banding. Ann Thorac Surg. 1995;60(6 Suppl):S523-4.

32. Matthews IL, Bjornstad PG, Kaldestad RH, Heiberg L, Thaulow E, Gronn M. The impact of shunt size on lung function in infants with univentricular heart physiology. Pediatr Crit Care Med. 2009;10(1):60-5.

33. Meng L, Xiao J, Gudelunas K, Yu Z, Zhong Z, Hu X. Association of intraoperative cerebral and muscular tissue oxygen saturation with postoperative complications and length of hospital stay after major spine surgery: an observational study. Br J Anaesth. 2017;118(4):551-62.

34. Dorrington $\mathrm{KL}$, Talbot NP. Human pulmonary vascular responses to hypoxia and hypercapnia. Pflugers Arch. 2004:449(1):1-15.

35. Heath D, Edwards JE. The pathology of hypertensive pulmonary vascular disease; a description of six grades of structural changes in the pulmonary arteries with special reference to congenital cardiac septal defects. Circulation. 1958;18(4 Part 1):533-47.

36. Wong RS, Baum VC, Sangwan S. Truncus arteriosus: recognition and therapy of intraoperative cardiac ischemia. Anesthesiology. 1991;74(2):378-80.

\section{Publisher's Note}

Springer Nature remains neutral with regard to jurisdictional claims in published maps and institutional affiliations.

Ready to submit your research? Choose BMC and benefit from:

- fast, convenient online submission

- thorough peer review by experienced researchers in your field

- rapid publication on acceptance

- support for research data, including large and complex data types

- gold Open Access which fosters wider collaboration and increased citations

- maximum visibility for your research: over $100 \mathrm{M}$ website views per year

At $\mathrm{BMC}$, research is always in progress.

Learn more biomedcentral.com/submission 